\title{
DEVELOPMENT OF CREATIVE POTENTIAL OF PUPILS BY MEANS OF FOLKLORE
}

\section{РОЗВИТОК ТВОРЧОГО ПОТЕНЦАЛУ МОЛОДШИХ ШКОЛЯРІВ ЗАСОБАМИ УСНОЇ НАРОДНОЇ ТВОРЧОСТІ}

\author{
Ruslana Liubar ${ }^{1}$ \\ Inna Liubar ${ }^{2}$ \\ DOI: https://doi.org/10.30525/978-9934-588-38-9-8
}

\begin{abstract}
For the harmonious and versatile development of each individual, today it is tremendously important to create the conditions for their creative self-realization. The article analyzes the process of becoming a creative personality, investigates the means of developing the creative potential of a pupils. Creativity in the scientific literature is determined by the highest form of human activity and its independence. Characteristic signs of creativity are purposefulness, possibility to have your own room for creativity, to think outside the box, readiness for productive fulfillment of new tasks, especially innovative ones. These indicators, as noted by researchers of the problem of creativity, can be both objective and subjective. Creativity implies the presence of certain personal and procedural characteristics: capabilities, motives, abilities, imaginations, intuitions, etc. The basis of creative activity include creative skills that reflect individual personality traits and research skills. The formation of creative personality skills is a purposeful process in which the significant component of activity is the attribute of manifestation of forceful efforts, internal goals, intentions, ie the ability to self-realization. Studies of psychologists and pedagogues show that the success of the development of the creative potential personality depends on many conditions, a special place is occupied by increasing cognitive activity, interest in educational activities, creating a comfortable environment for learning and upbringing, the development of initiative,
\end{abstract}

${ }^{1}$ Candidate of Pedagogical Sciences, Associate Professor,

Head of the Department of Methods of Music Education, Singing and Choral Conducting,

Kryvyi Rih State Pedagogical University, Ukraine

${ }^{2}$ Associate Professor, Associate Professor of the Department of Primary Education,

Kryvyi Rih State Pedagogical University, Ukraine 
creative thinking. Scientists consider creative activity as a reflection of the personality of their own essence, which reveals a unique individuality, the capacity for activities having an original character, productive-positive value, progressiveness and moral orientation. The structure of creative activity of pupils is viewed through a system of motives, creative abilities and skills. The scientists confirmed that formation of creative activity attitude of people is one of the pedagogical conditions of development of creative potential. A number of researchers consider the concept of creative personality as a person who possesses certain qualities, abilities, peculiarities of mental processes, through which its activity is a different novelty, originality, for which the need for creativity is a vital necessity and has the most creative style characteristic. In the structure of the creative personality, scientists distinguish such sub-structures as: motivational orientation of the individual to creativity, individual-personal qualities, creative skills and peculiarities. A person's ability to be creative is called creativity. The creative potential of the child is the high creative capacity of the individual, which is realized in successful creative activity. Indicators of creative potential development among children are defined as follows: successful learning, developed memory, original thinking, active interest in solving difficult problems, curiosity, desire to fantasize, ingenuity, communicativeness. These children have a high level of special abilities development, particular in the sphere of art, language and literature, physics and so on.

The development of the creative potential of pupils is promoted by folk art, including folk songs and riddles, proverbs and sayings, fairy tales and legends that accumulate everything that ensures its holistic spiritual development. Folklore knowledge, which is acquired in elementary school will help to form the culture of personality among pupils in the secondary and high school as a form of regulation of their creative interaction with society and the surrounding natural world.

\section{1. Ветуп}

Для гармонійного й різнобічного розвитку кожної особистості важливим є створення умов для iї творчої самореалізації. Оновлення сучасної школи зумовлює потребу в професійних і творчих фахівцях, компетентних у питаннях сучасного навчання та виховання, підтримки інтелектуально-творчого росту особистості. Тому особливого 
значення у навчальних закладах України сьогодні набуває модернізація змісту і технологій навчально-виховного процесу як системи особистісно-творчого становлення школярів.

Психологічні аспекти творчої діяльності досліджуються I. Бехом, Д. Богоявленською, А. Брушлинським, Л. Виготським, О. Матюшкіним, О. Моляко, Я. Пономарьовим, В. Роменцем та ін.

Розвиток творчого потенціалу особистості $\epsilon$ важливою умовою виховання людини. Творчий потенціал особистості вивчали вчені: Л. Вяткін, С. Глухівська, В. Загвязинський, Н. Зайцева, М. Матюшкін, В. Моляко, В. Риндак та ін.

Більшість досліджень присвячено вивченню окремих якостей творчої особистості. Сьогодні зростає потреба у дослідженні цілісного процесу творчої реалізації молодших школярів, структурних компонентів творчого потенціалу особистості, засобів його розвитку.

Метою даної роботи є розгляд та аналіз сучасних досліджень проблем творчості, вивчення процесу становлення творчої особистості та розкриття засобів розвитку творчого потенціалу молодшого школяра.

\section{2. Теоретичні аспекти дослідження творчості}

Теоретичним проблемам творчості присвячені дослідження філософів Г. Батищева, І. Бичка, I. Зазюна, А. Кочергіна, П. Кравчук, О. Спіркіна, А. Шумиліна та ін.

Творчість у науковій літературі визначається вищою формою активності й самостійності людини. Характерними ознаками творчості є цілеспрямованість, оригінальність мислення, готовність до продуктивного виконання нових завдань, особливо новаторських. Ці показники, як зазначають деякі дослідники проблематики творчості (Л. Виготський, П. Еббс, В. Загвязинський, В. Роменець, О. Рудницька, С. Сисоєва та ін.), можуть бути як об'єктивними, так і суб'єктивними. Об'єктивна цінність визначається за соціально значущими продуктами творчості, які не мали аналогів в історії культури. Суб'єктивна цінність має місце тоді, коли продукт є новим лише для людини, котра його створила. Сама суб' єктивна навизна думок, рішень, оцінок, позицій, почуттів властива навчальній творчості [17, с. 73].

Аналіз філософських праць дає змогу розглядати творчість як процес людської діяльності, що створює якісно нові матеріальні й 
духовні цінності. Види творчості визначаються характером творчої діяльності (творчість винахідника, організатора, наукова і художня творчість і т. ін.) [25, с. 363].

Від епохи античності й до сучасності існували різні трактування поняття творчості. Платон розглядав художню творчість як божественну одержимість, Шеллінг як синтез свідомого і несвідомого, Бергсон як містичну інтуїцію, Фрейд як прояв інстинктів. У процесі творчості беруть участь всі духовні сили людини, в т. ч. уява, а також існуюча в навчанні і в практиці майстерність, необхідна для здійснення творчого задуму [25, с. 364].

Будучи за своєю сутністю культурно-історичним явищем, творчість має психологічний аспект: особистісний та процесуальний. Вона передбачає наявність у особистості здібностей, мотивів, знань і умінь, завдяки яким створюється продукт, що відрізняється новизною, оригінальністю, унікальністю. Вивчення цих властивостей особистості виявило важливу роль уяви, інтуїції, неусвідомлюваних компонентів розумової активності, а також потреби особистості в самоактуалізації, в розкритті й розширенні своїх творчих можливостей. Англійський учений Г. Уоллес виділив чотири стадії процесів творчості: підготовку, дозрівання, осяяння і перевірку. Центральним, специфічно творчим моментом вважалося осяяння - інтуїтивне схоплення бажаного результату [10, с. 351].

У педагогічному словнику творчість розглядається як продуктивна людська діяльність, здатна породжувати якісно нові матеріальні та духовні цінності суспільного життя. Розвиток творчого потенціалу діяльності є важливою умовою культурного прогресу суспільства й виховання людини. Тому на всіх щаблях школи (початкової, середньої, вищої) слід звертати особливу увагу на формування в учнів різноманітних, глибоких і міцних систем знань, на максимальну стимуляцію самостійної діяльності учнів, на розвиток стійких творчих інтересів, цілеспрямованості творчих пошуків, наполегливості під час виконання творчих завдань [7, с. 326].

Л. Виготський про феномен творчості писав: «...У щоденному оточуючому нас житті творчість є необхідною умовою існування, і все, що виходить за межі рутини і в чому полягає хоч йота нового, зобов'язане своїм походженням творчому процесу людини» [1, с. 7]. 
В. Загвязинський зазначає, що творчість в особистісному аспекті, незалежно від виду діяльності, в якої вона проявляється, характеризується такими рисами, як прагнення до нового, здатність до аналізу і самоаналізу, гнучкість і широта мислення, воля і уява [5].

В діяльнісному аспекті творчість позначається як створення якісно нових матеріальних або духовних цінностей. Такий вид діяльності характеризується нешаблонністю, та є проявом індивідуальності людини-творця. Вважається, що неможливо навчити людину творчості, але педагогічна система може сформувати необхідні передумови творчої активності, які, змінюючи структуру навчальної діяльності, стануть чинником формування творчої особистості [24].

\section{3. Основи творчої діяльності}

Актуальним у педагогіці залишаються питання формування творчих вмінь особистості.

До основних умінь творчої діяльності Г. Нікітіна і В. Романенко відносять творчі уміння, які відображають індивідуальні риси особистості та дослідницькі вміння. На будь-якому рівні діяльності творчі уміння поділяються на три ієрархічних ступеня - базовий, професійний і вищий. Для адаптації їх у педагогічних умовах авторами пропонуються такі рівні: творчі вміння вищого ступеня (набір імпровізаційних умінь, що сприяють розвитку таланту учня, який самостійно створює і вдосконалює творчі дії на основі розвиваючого завдання); творчі вміння професійного ступеня (набір спеціальних умінь, які пов'язані із головним видом творчої діяльності й освоєні учнем за підтримки вчителя); дослідницькі вміння (набуваються учнем у запам'ятовуванні в процесі взаємодії із вчителем) [16, с. 98].

Дослідник Павленко О. стверджує, що сутність творчого вміння полягає в оволодінні теоретичними (розумовими) і практичними діями в їх єдності, спрямованими на успішне виконання творчої діяльності, що вказує на новий продуктивний рівень активності особистості, відображаючи ії гуманістичну й прогресивну спрямованість. Творчі вміння мають такі характерні ознаки, як новизна, оригінальність, значущість для самої особистості або суспільства. У науковій літературі поняття «творчі вміння» розуміють як: властивість людини на основі знань і навичок успішно досягати свідомо поставленої мети діяльності в мін- 
ливих умовах її перебігу (Є. Мілерян); новий «сплав» знань, навичок, досвіду і творчих можливостей людини (Н. Кузьміна); володіння такою діяльністю, яку треба здійснювати не автоматично, а з творчим використанням знань і навичок (Л. Барабанщиков, С. Сисоєва, Л. Спірін, О. Щербаков); операції інтелектуальної власності з істотною ознакою узагальнень, внаслідок чого вони реалізуються у змінених і різноманітних ситуаціях (Г. Щукіна) [17, с. 73].

Л. Онофрійчук вважає, що творчі уміння є результатом оволодіння творчою дією за допомогою прийомів інтелектуальної, художньо-практичної діяльності, які передбачають самостійність вирішення творчих завдань, опанування спеціальних знань та їх практичне застосування. Формування творчих умінь особистості, як зазначає дослідниця, залежить від іiі внутрішніх якостей (розумових, естетичних, моральних, трудових) та психічних властивостей (пам'ять, увага, почуття, уява, мислення, воля), які реалізуються через діяльність і творчість [17, с. 73].

Розкриваючи зміст поняття «формування творчих умінь», О. Клепіков та I. Кучерявий зазначають, що це - цілеспрямований процес, в якому необхідним компонентом активності $є$ властивість прояву вольових зусиль, внутрішніх цілей, намірів і задумів, тобто здатність до самореалізації. Воля - головне джерело творчих резервів особистості, яка виявляє такі якості, як зібраність, сміливість, наполегливість і цілеспрямованість. Сильна воля скріплює і приводить у дію всі природні нахили і навички, які придбала і розвинула особистість. Тому рушійними силами творчого процесу є саме емоційно-вольові характеристики особистості [9, с. 41-42].

Ряд дослідників через призму творчої активності розглядають поняття творчої особистості.

У науковій літературі існує значна кількість підходів до визначення поняття «творча особистість». Більшість науковців відзначають, що творча особистість - це людина, якій притаманні певні якості, здібності, особливості психічних процесів, завдяки яким iї діяльність відрізняється новизною, неповторністю, оригінальністю, для якої потреба у творчості є життєвою необхідністю, а творчий стиль діяльності - найбільш характерним [21, с. 4]. Межі творчості такої особистості охоплюють дії від нестандартного розв'язування простого завдання до нової реалізації унікальних потенцій індивіда в певній галузі, і при- 
таманні ій такі якості, як рішучість, вміння не зупинятися на досягнутому, сміливість мислення, вміння бачити далі ніж бачать її сучасники і що не бачили їі попередники [27, с. 7].

П. Енгельмейєр вважає, що творча особистість являє собою прогресивний елемент, який дає все нове» [8, с. 3]. В. Моляко визначає творчу особистість як людський індивід, який прагне до оригінального нового і заперечує звичайне, і вважає, що творча особистість вирізняється високим рівнем знань, умінь, може аналізувати явища й порівнювати їх [15, с. 16-17].

Дослідники виявляють і називають найбільш вагомі, на їх погляд, якості, здібності і здатності, які залежать від того, що саме вони вкладають у поняття «творча особистість». Проблема набуває значущості ще й через те, що від поєднання унікальних особистісних, психологічних, фізичних характеристик залежить неповторний стиль і результат творчості кожної особистості. У сучасних дослідженнях творчості все виразніше проступає підхід, згідно з яким всі особливості, якості, здібності переплітаються між собою, впливаючи одна на одну, що зумовлює необхідність досліджувати структуру особистості у комплексі та взаємодії усіх компонентів, які безпосередньо впливають на творчу особистість [28, с. 25].

Досліджуючи структуру особистості, К. Платонов виділив в ній чотири підструктури: соціально-обумовлену підструктуру спрямованості особистості; підструктуру досвіду; підструктуру психічних процесів, куди увійшли властивості та якості особистості; підструктуру біопсихічних властивостей особистості [18, с. 137-141].

В. Андрєєв зазначає, що творча особистість у своєму розвитку проходить певні етапи: вибіркової мотиваційно-творчої спрямованості особистості на певну діяльність, інтелектуально-творчого потягу особистості до певного виду діяльності, підвищеної професійно-творчої активності особистості в певному виді діяльності, перших значних творчих досягнень, стійкої творчої продуктивної діяльності особистості, розвитку таланту, геніальності [28, с. 26].

Г. Яківчук у структурі творчої особистості виділяє такі їі підструктури, як: мотиваційна спрямованість особистості до творчості, індивідуально-особистісні якості, творчі уміння і якості [28, с. 28].

Дослідження творчих якостей і здібностей особистості здійснювали В. Андрєєв, Д. Богоявленська, А. Брушлинський, В. Кан-Калик, 
Г. Костюк, О. Лук, А. Матюшкін, В. Моляко, А. Пономарьов, М. Поташник, В. Роменець, С. Сисоєва та ін., які виділили найбільш суттєві складові творчої особистості [28, с. 25]. Так, А. Матюшкін наголошував, що творчість виявляється на всіх етапах індивідуального розвитку особистості і залежить від пізнавальної мотивації особистості, творчої активності, яка проявляється у винайденні нового, постановці та вирішенні проблем, здатності до створення еталонів, які $є$ основою формування естетичних, моральних, інтелектуальних, ціннісних орієнтацій [14, с. 134].

А. Лук акцентував увагу на мотивації творчості, розділяючи творчі здібності на три групи: пов'язані з мотивацією (інтереси і схильності), пов'язані з темпераментом (емоційність), розумові здібності [12, с. 73].

У процесі творчої діяльності реалізуються творчі можливості особистості й здійснюється їх розвиток: особливість процесу творчості полягає у тому, що його перебіг впливає на результат, який виражається не тільки предметно, а й у зміні самого суб'єкта творчості. Крім того, творчі можливості особистості реалізуються не тільки в спеціальній діяльності зі створення загальнокультурних цінностей, а й у самому процесі життя людини, життєтворчості [20, с. 89].

\section{4. Творчий потенціал особистості}

Тривалий час досліджується проблема діагностування здатності людини до творчості, тобто вимір іiі творчого потенціалу. Властивості творчого потенціалу поділяють на: предметні, аксіологічні, пізнавальні, комунікативні та художні.

В сучасних психолого-педагогічних дослідженнях розуміння терміну «творчий потенціал особистості» $є$ досить багатоаспектним. Творчий потенціал особистості розглядається науковцями з різних позицій, а саме як: ресурс творчих можливостей людини, здатність конкретної людини до здійснення творчих дій, творчої діяльності (В.О. Моляко); соціально-психологічна установка на нетрадиційне розв'язання протиріч об'єктивної реальності (Є.В. Колеснікова); синтетичну (інтегруючу) якість, що характеризує можливості особистості, яка здійснює діяльність творчого характеру (І.О. Мартишок та В.Ф. Овчинніков); сукупність реальних можливостей, вмінь і навичок, які тою чи іншою мірою визначають рівень їх розвитку (Г.Л. Піхтовщиков та Л.І. Московичева); характерну властивість індивіда, що визначає його можли- 
вості в творчому самоздійсненні та самореалізації (М.В. Котюсова); спеціальну якість, що відображує ступінь відповідності діяльнісних якостей індивіда соціальній нормі (певним соціальним ролям), що вимагається від суб' єкта творчості (С.Р. Евінзон) [11, с. 99].

До структурних компонентів творчого потенціалу особистості А.В. Лукановська відносить [13, с. 635-643]:

- розвинуту уяву;

- якість мислення (гнучкість, оригінальність, швидкість, самостійність);

- наполегливість у досягненні поставленої мети;

- надання переваги складному перед простим;

- активна життєва позиція;

- цілеспрямованість;

- збалансована вимогливість до результатів своєї праці;

- пристрасть до впорядкування, систематизація наявних знань та уявлень;

- духовність.

Дослідник О. А. Листопад зазначає, що творчий потенціал особистості проявляється у двох аспектах поведінки: інструментальному (способи творчої діяльності дитини) та мотиваційному (вибірковість інтересів, пізнавальні потреби та ініціативи тощо). Серед основних якостей прояву інтелектуальних здібностей, які можуть спостерігатися педагогом в цілях виявлення дітей $з$ високим творчим потенціалом дослідник виділяє: пам'ять - здатність дитини швидко запам'ятовувати і утримувати довгий час в пам'яті різну інформацію (вербальну, зорову, рухову); увага - здатність дитини швидко концентруватися, «налаштовуватися» на діяльність і довгий час нею займатися не відволікаючись; здібність до аналізу і синтезу - здатність дитини швидко «розкладати» запропоновану інформацію на складові iї частини або, навпаки, 3 декількох частин створювати ціле (робити висновки); продуктивність мислення; здатність дитини на поставлену перед ним проблему знаходити велику кількість рішень; старанність прагнення дитини доводити результати своєї діяльності до відповідності найвищим стандартам; гнучкість мислення - здатність дитини швидко змінювати свою поведінку, вносити корективи до своєї діяльності залежно від обставин, що змінилися, об’єднувати в своїй діяльності знання і уміння з різних сфер життя; оригінальність мислення - здатність дитини висувати 
нові, нестандартні ідеї, бачити «незвичайне» в звичайному, діяти не як всі; здатність знаходити альтернативи; здатність передбачати, прогнозувати наслідки; прагнути завжди перевіряти нову ідею; здатність захоплюватися; здатність не лише пропонувати, але і розробляти ідеї; схильність до логічних міркувань; здатність оперувати абстрактними поняттями; здатність уловлювати зв'язки між причиною і наслідком; постійне бажання ставити багато питань тощо [11, с. 101].

Творчий потенціал характеризується низкою якостей, які демонструє творча особистість. Серед таких якостей вчені називали здатність побачити проблему з незвичної точки зору, відмовлятися від авторитетів, уникати передбачених рішень, легко викликати і комбінувати асоціації та образи, критично оцінювати ситуації та явища тощо [26, с. 246].

Дослідження психологів і педагогів показують, що успішність розвитку творчого потенціалу особистості залежить від багатьох умов, серед яких особливе місце займають підвищення пізнавальної активності, інтересу до навчальних занять, створення комфортного середовища для навчання та виховання, розвиток ініціативи, творчого мислення.

У психолого-педагогічній науці існують різні підходи до визначення творчої активності особистості.

Активність визначає якість діяльності, але досить специфічно через ставлення суб'єкта, яке включає готовність, прагнення діяти, бажання зробити роботу швидше, енергійніше, проявити ініціативу $[12$, с. 27]. Творча активність - це відображення особистістю власної сутності, в якій розкривається неповторна індивідуальність, здатність до діяльності, що має оригінальний характер, продуктивно-позитивну цінність, прогресивність та моральне спрямування [28, с. 26].

Дослідниця О. Граматюк розглядає творчу активність школярів як інтегративну якість особистості, зумовлену його біологічними, фізіологічними, психологічними, соціальними особливостями, що забезпечує можливість та готовність виконувати ініціативні, новаторські дії під час розв'язання будь-яких проблемних ситуацій або складних навчальних задач та зумовлює в процесі самовираження, самореалізації та самовдосконалення наявність нового, оригінального, ефективного результату [3, с. 224].

Структуру творчої активності молодших школярів В. Сачок розглядає через систему мотивів, творчих здібностей, умінь творчої 
діяльності, які об’єднані в два компоненти: емоційно-мотиваційний i змістовно-операційний. Емоційно-мотиваційний компонент передбачає наявність у молодших школярів спрямованості на творчу діяльність, яка виражається в допитливості та інтересі до улюбленого виду діяльності, в активності, ініціативності, самостійності при виконанні завдань творчого характеру. Змістовно-операційний компонент покликаний забезпечити реалізацію спонукань до творчої діяльності школярів [19, с. 198].

Формування ціннісної установки на творчу активність людей науковці називають однією з педагогічних умов розвитку творчого потенціалу особистості.

Поняття «установка» було введено до наукового обігу німецьким вченим К. Ланге наприкінці XIX століття в якості позначення готовності до дій, обумовленої наявним досвідом. Глибоке і грунтовне дослідження установки ми знаходимо в працях Д. Узнадзе, який визначав, що це цілісний динамічний стан готовності суб'єкта до активності, який зумовлюється внутрішньою потребою і зовнішніми обставинами суб'єкта. Активізуючим чинником формування установки є цінність. Ціннісний компонент стає регулятивним елементом установки, який впливає на всю iï структуру. Стимулювання ціннісної установки на творчу активність відбувається за допомогою творчих завдань, які перетворюють освітній простір з регламентованої системи трансляції знань на творчу лабораторію [26, с. 246].

Наступною педагогічною умовою формування творчого потенціалу науковці визначають організацію креативно орієнтованого розвивально-освітнього середовища на основі поваги до особистості, динамічності й активності всіх суб'єктів освітнього процесу, рефлексивності, діалогічності, посиленні уваги до дослідної діяльності, наявності сприятливої психологічної атмосфери [26, с. 247]. Психологічна атмосфера навчально-розвивального середовища розуміється як стиль, емоційне забарвлення спілкування, стійкий емоційний фон, який виникає в процесі спільної діяльності [2].

Третьою умовою дослідники визначають організацію психологічного супроводу розвитку творчого потенціалу особистості, що полягає у співпраці учня та вчителя, допомозі наставника у реалізації творчих здібностей дитини. 


\section{5. Реалізація творчого потенціалу дитини}

Починати процес залучення дітей до творчого пошуку, реалізації творчих задумів педагоги рекомендують якомога раніше.

Беручи участь у творчому процесі, дитина відбиває в ньому своє розуміння життєвих цінностей, свої особистісні властивості, по-новому осмислює їх, переймається їхньою значимістю й глибиною. Художньо-творча діяльність розвиває естетичні почуття дитини. Через цю діяльність формується естетична сприйнятливість дитини до світу, оцінювання прекрасного. Формування здатності до художньо-творчої самореалізації дітей 4-5 річного віку - це особлива форма якісного переходу від вже відомого до чогось нового, невідомого. У дітей даного віку цей перехід відбувається в процесі різноманітних форм пошукової творчої діяльності, яка направлена на вирішення нових, незвичних для дитини завдань. Чим різноманітніші випробувальні дії дітей, тим гнучкіша та оригінальніша художньо-творча діяльність, тим більше можливості отримати в кінцевому висновку новий, незвичний результат [6, с. 157].

Даний віковий період розвитку дітей характеризується високою сензитивністю, в результаті чого діти проявляють дивовижні вигадки та винахідливість. Завдяки формуванню здатності до художньо-творчої самореалізації дитина спроможна отримати той новий художній матеріал, на основі якого будуть потім будуватися оригінальні задуми, ідеї, створюватися нові малюнки, мистецькі твори і т. п. Отже, художньо-творча самореалізації дітей 4-5 річного віку - це цілісний процес розкриття та ефективного використання дошкільниками свого творчого потенціалу і здібностей в різних видах мистецької діяльності, що здійснюється на основі вільного вибору і забезпечує позитивний результат особистісного розвитку [6, с. 157].

Серед вагомих засобів виховання творчого потенціалу особистості дослідники виділяють усну народну творчість. Дитячий фольклор розвивався у міцному зв'язку з фольклором дорослих. Але існують зразки усної творчості, які характерні тільки для дитячого фольклору: небилиці, лічилки, кричалки, страшилки, скоромовки та ін.

Небилиці та нісенітниці не лише розважають дітей, а й примушують замислитись над дійсною логікою речей та співвідношень у світі, фантастичні казки слугують розвитку розумових навичок та етичних 
установок, загадки розвивають асоціативне мислення, навчають спостерігати подібність предметів та явищ, розпізнавати їх за метафоричним описом. Найяскравіше відобразилася дитяча творчість у дитячих піснях.

В дитячому репертуарі $\epsilon$ пісні, в яких головними героями $є$ численні представники живого світу: тварини, птахи, рослини. У цих піснях дійові особи - люди - з'являються рідко, частіше людськими вадами наділяються інші живі істоти. $Є$ сюжети народних пісень, де працелюбство тварин та птахів ставало для дітей повчальним прикладом, контрастом до неробства окремих людських персонажів.

Два півники, два півники

Горох молотили,

Дві курочки, дві курочки

На піч ізносили,

Два котики, два котики

У млин ізвозили.

3 семи років гра дитини раніше поєднувалася з серйозним заняттям випасанням домашньої худоби, ігри переносилися вже в поле, на вигін. Про це діти співали у своїх творах. У зверненнях до тварин вони використовували постійні епітети: зайчик - білоданчик, вовчок - сірячок, лисичка - сестричка, сорока - білобока, що підкреслювало характерні ознаки цих істот. Інтерес дітей до навколишнього світу сприяв заповненню ігрових творів таким персонажами, як зайчик, перепілка, горобець та ін.

У піснях діти використовували наслідування голосам та інтонаціям навколишнього світу. «Наслідування - один з типів тимчасових зв'язків, що мають велике значення в житті дитини» [4, с. 125], - писав психолог Д. Ельконін, маючи на увазі різні види наслідування, в тому числі й звукам, завдяки чому людина здатна засвоювати мову. 3 часом цю здатність вже достатньо розвинена дитина перетворює на розвагу, а звукоуподібнення міцно входить у сферу естетичних уподобань дітей. Наприклад, наслідуючи кумкання жаб, діти промовляють:

- Кум, кума!

А де-сь була?

- На яр...яр...яр....марку.

- А шо-сь купила?

- Черевики-кі-кi-кi,

Черевики-кі-кі-кі. 
Часткою світу дитини були різноманітні форми поєднання реального й фантастичного. Це виявилось у закличках, які були відомі давнім народам і виконували важливі функції в первісному суспільстві.

«Кожна дитина на певному етапі розвитку схильна в своїй уяві наділяти властивими їй самій якостями - розумом, мовою - не лише живі істоти, але й явища та неживі предмети, звертатися до них, щиро вірячи, що ï чують та розуміють. 3 віком беззастережність такої віри послаблюється, але привабливість їі не зникає, і пісні-заклички набирають все яскравіше виявленої ігрової функції» [4, с. 94].

Найпоширенішими є заклички до дощу, сонця, хмар, вітру, грому, в яких є звернення - щоб пішов дощ, вийшло сонце, розійшлися хмари.

Гримить, гримить-

Голова не болить;

Нехай тоді болить,

Коли у воді камінь згорить.

Діти завжди лагідно звертаються до сонечка:

Сонечко, сонечко,

Виглянь у віконечко,

Дітки гуляють,

Тебе виглядають.

У закличках також згадуються різні істоти: птахи, комахи. Це змальовує картину, сповнену певними образами і настроєм.

Дошчику, дощчику

Наваримо боричику

В зеленому горщику;

Поставимо на горі,

Виїять комарі;

Залишиться трошки,

Виїять мошки;

Останеться крапля,

Виїсть чапля;

Залишиться кришка,

Виїсть мишка.

Діти прохали у природи сприяння господарським роботам дорослих у селі: сонце - вигріти дідове поле, бабину городину, дощ - полити дідові дині, бабині капусти тощо: 
Вийди, вийди, сонечко,

На дідове полечко,

На бабине зіллячко,

На наше подвір'ячко.

Ряд науковців у закличках прослідковують сліди магічних вірувань. У багатьох народів світу поширені твори, присвячені комасі «сонечко» (божа коровка), що були своєрідним ворожінням по напряму лету комахи. Також відомі заклички до лету ластівки, журавля.

Через заклички діти намагалися вплинути на поведінку живої істоти:

Чорногузе-дядьку,

Зроби мені хатку

Іставок, і млинок,

І цүибулі грядку.

За допомогою закличок відганяли шуліку від курчат, спостерігали життя комах, зокрема мурашок:

мурашка, мурашка,

Садовая кашка,

Дай мені кваску,

А я тобі медку.

Отже, заклички знайомили дітей з явищами навколишнього світу, розвивали цікавість, супроводжували їх улюблені розваги, спонукали до творчості.

Протягом багатьох віків діти зверталися до стихій та явищ природи, комах, птахів та рослин, одухотворюючи їх у своїй уяві, що яскраво виразилося у різновиді закличок - примовках.

Побачивши весною диких гусей, діти кидали їм солому і примовляли:

Гуси, гуси!

Нате вам на гніздечко,

А нам на здоров'ячко.

Побачивши вперше весною ластівку, діти промовляють і кидають камінці за ластівкою, а потім умиваються, щоб позбутися веснянок:

Ластівки, ластівки,

Візьміть собі веснівки,

Нате вам камінці,

Дайте мені рум'янщі. 
В примовках виражалися дитячі емоції, викликані спілкуванням 3 живими істотами, природніми явищами, примовки були супроводом певних дій.

Багато радісних пісень створили діти, зустрічаючи весну:

Розлилися води

На чотири броди.

Ой діти-квіти,

Весна-красна,

Зілля зелененьке.

Своєрідно відображаючи окремі сторони реального життя та побуту, дитячі пісні служили й справі виховання у їхніх носіїв простих соціальних почуттів - любові, співчуття, жалості. Стикаючись у своїх творах із птахами, звірятами, комахами, які в поетичній уяві могли думати, говорити, діяти, страждати, радіти і які в більшості випадків були добрими, дружелюбними, часом слабкими і беззахисними, дитина вчилася відчувати себе частиною великого світу природи. I любов до нього, безсумнівно, підтримували, посилювали народні дитячі пісні. Слухачі й виконавці в міру своєї емоційності, багатої уяви співпереживали дії, вчинки, стани персонажів пісень, що полегшувало сприйняття ними й повчального елементу творів, зокрема тих, де зображена безжальність, мусила викликати переживання, протест, заперечення іiі маленьким виконавцем чи слухачем [23, с. 13].

Знайомлять дітей 3 навколишнім світом і найважливішими правилами людського спілкування за допомогою алегоричних художніх образів українські народні казки: «Лисичка, котик і півник», «Солом’яний бичок», «Коза-дереза», «Пан Коцький», «Лисичка-сестричка i вовк-панібрат» та ін.

Отже, усна народна творчість (оповіді, загадки, приказки, прислів'я, заклички, лічилки, казки, пісні та ін.) увібрала багатий досвід дитячої творчості, що повинен стати особистою цінністю для кожної дитини.

Головною умовою розвитку творчого потенціалу є включення дітей до активної пізнавальної творчої діяльності у навчальному закладі. В початковій школі разом з наданням елементарних знань про природу, суспільних взаємозв'язків, повинен відбуватися розвиток ціннісного ставлення школярів до культурної спадщини народу, вивчення кращих зразків дитячого фольклору, і на даному матеріалі - формування 
елементів творчої діяльності дітей. Досягається це шляхом усунення формального підходу до вивчення усної народної творчості. Уміле використання дитячого фольклору виховує в учнів повагу до мистецтва, природи, дає відчуття творчої взаємодії з нею, спонукає дітей до творчої пізнавальної діяльності.

Процес залучення школярів до вивчення народної дитячої творчості в початковій школі повинен відбуватися не тільки при викладанні предметів мистецького та мовно-літературного циклів, а і природничого, де на кожному уроці розкриваються нові уявлення та поняття про об'єкти, явища природи, їхні взаємозв'язки та наслідки людської діяльності на стан природи. Адже у кращих зразках усної народної творчості відбилося розуміння явищ природи, давалися поради щодо поведінки людей, їхньої праці, збереження здоров'я тощо.

В творчу роботу на уроках переходить спостереження за явищами природи, що зафіксовано у прислів'ях і приказках:

Осінь іде - доші за собою веде.

Де багато пташок, там нема комашок.

Така діяльність має велике значення у навчанні й розвитку дітей молодшого шкільного віку. Щодня на уроці діти можуть перевіряти народні прикмети про особливості пори року, зміни в погоді тощо.

Іноді молодші школярі можуть неправильно розуміти багато явищ природи, тому необхідно вчителю у доступній цікавій формі розкривати складну систему взаємозв'язків у природі, розвивати увагу і спостережливість, вчити розуміти красу навколишнього світу, спостерігати за тваринами та рослинами, перевіряти певні народні прикмети, розгадувати таємниці природних явищ тощо.

Велике значення видатний український педагог В. Сухомлинський приділяв естетичній творчості дітей: «Кожна людина освоює і красу природи, і музичну мелодію, і слово. I це освоєння залежить від його активної діяльності, під якою ми розуміємо працю і творення, думку і почуття, що сприймають, створюють і оцінюють красу. Чим більше в природі предметів, олюднених емоційним сприйняттям, пережитих як краса навколишнього світу, тим більше краси бачить людина навколо себе, тим більше хвилює, зворушує його краса - і створена іншими людьми, і первозданна, нерукотворна. Тих дітей і підлітків, для яких постійне спілкування з природою стало важливим елементом 
їхнього духовного життя, глибоко хвилюють, чіпають описи природи в художніх творах, зображення картин природи в творах живопису» [22, с. 380]. Педагог радив вчителям разом 3 дітьми займатися творчістю: складати твори-мініатюри про навколишній світ, спостерігаючи явища природи; виготовляти картини з природних матеріалів, прикрашаючи класи, наочні приладдя для кабінетів природничих дисциплін тощо. В. Сухомлинський наголошував, що пов'язуючи з творчею працею радісні, піднесені думки і почуття, ми облагороджуємо душі наших вихованців [22, с. 106].

Корисними у творчій діяльності дітей є загадки. Вони містять у собі умову і запитання, на яке треба дати відповідь. Це спонукає до роботи мислення дитини, сприяє розвиткові кмітливості, винахідливості. Діти на основі спостережень можуть самостійно складати загадки.

Особливої уваги варто приділяти в школі проведенню народних свят, в яких яскраво відбилися народні традиції та обряди - Свято зустрічі весни, День першого снопа, День зимового Сонцестояння, Свято першого хліба, Літній сінокіс та ін. Беручи безпосередньо участь у заходах, школярі не тільки вивчають народні свята, а й вигадують цікаві сюжети, яскраві образи, костюми.

\section{6. Висновки}

Творчий потенціал дитини ми розглядаємо як високі творчі можливості особистості, які реалізуються в успішній творчій діяльності. Високі творчі можливості особистості виявляються або будуть виявлятися у творчих успіхах.

Показниками розвитку творчого потенціалу в дітей визначено: успішне навчання, розвинута пам'ять, оригінальне мислення, активний інтерес до вирішення складних завдань, допитливість, прагнення фантазувати, винахідливість, комунікативність. Ці діти мають високий рівень розвитку спеціальних здібностей, зокрема до мистецтва, мови i літератури, фізики тощо.

Розвитку творчого потенціалу молодших школярів сприяє усна народна творчість, зокрема народні пісні і загадки, прислів'я і приказки, казки і легенди, в яких акумулювалося все, що забезпечує цілісний духовний розвиток. Набуті у початковій школі знання народної творчості сприятимуть формуванню духовної культури школярів 
середнього і старшого віку як форми регуляції їх творчої взаємодії 3 суспільством та навколишнім природнім світом.

Виконане дослідження не вичерпує всіх аспектів порушеної проблеми. Подальшого розгляду потребують форми і методи комплексного впровадження кращих зразків усної народної творчості у навчально-виховний процес початкової школи, проблеми апробації сучасних креативних технологій навчання та виховання молодших школярів.

\section{Список літератури:}

1. Ананьев Б.Г. Человек как предмет познания. Ленинград : Изд-во Ленинградского университета, 1968. 335 с.

2. Баранова Н. Психологічний клімат у колективі. Київ : Редакція загальнопедагогічних газет, 2003. 143 с.

3. Граматюк О. Діагностика стану розвитку творчої активності учнів 9-11 класів. Наукові записки / ред. кол.: В.В. Радул, В.А. Кушнір та ін. Кіровоград : РВВ КДПУ ім. В. Винниченка, 2015. Випуск 139. Серія : Педагогічні науки. 316 с.

4. Довженок Г.В. Український дитячий фольклор : віршовані жанри / Київ : Наукова думка, 1981. 170 с.

5. Загвязинський В.І. Педагогічна творчість учителя. Педагогічна творчість і майстерність: хрестоматія / укл. Н.В. Гузій. Київ : ІЗМН, 2000. 168 с.

6. Іваненко А. Методичні засади формування художньо-творчої самореалізації дітей 4-5 років у процесі музичних занять. Науковий часопис Національного педагогічного університету імені М.П. Драгоманова. Серія 14. Теорія і методика мистецької освіти : збірник наукових праць. Київ : НПУ ім. М.П. Драгоманова, 2014. Вип. 16(21). Частина 2. 253 с.

7. Гончаренко С. Український педагогічний словник. Київ : Либідь, 1997. 376 с.

8. Енгельмейер П.К. Теория творчества. Москва : Образование, 1910. 216 с.

9. Клепиков О.І. Основи творчості особи : навч. посібник. Київ : Вища школа, 1996. 295 с.

10. Краткий психологический словарь / сост. Л.А. Карпенко; под общ. ред. А.В. Петровского, М.Г. Ярошевского. Москва : Политиздат, 1985. 431 с.

11. Листопад О.А. Діагностування творчого потенціалу особистості дитини. Наука і освіта. Київ, 2013. № 3. С. 99-101.

12. Лук А.Н. Психология творчества. Москва : Наука, 1978. 127 с.

13. Лукановська А.В. Творчий потенціал особистості : структурні компоненти. Проблеми сучасної психологї̈. Київ, 2010. Вип. 8. С. 635-643.

14. Матюшкин А.М. Проблемные ситуации в мышлении и обучении. Москва : Педагогика, 1972. 208 с.

15. Моляко В.А. Психология творческой деятельности. Киев : Знание, 1978. $47 \mathrm{c}$.

16. Никитина Г.В. Формирование творческих умений в процессе профессионального обучения. Санкт-Петербург : Издательство С.-Петербургского университета, 1992. 168 с. 
17. Павленко О.М. Джазова імпровізація як засіб розвитку творчих вмінь майбутнього вчителя музики. Науковий часопис Національного педагогічного університету імені М.П. Драгоманова. Серія 14. Теорія і методика мистецької освіти : збірник наукових праць. Київ : НПУ ім. М.П. Драгоманова, 2014. Вип. 16(21). Частина 2. 253 с.

18. Платонов К.К. Структура и развитие личности. Москва : Наука, 1986. 251 с.

19. Сачок В. Особливості форм творчої роботи вчителя музичного мистецтва з учнями початкової школи. Наукові записки / ред. кол.: В.В. Радул, В.А. Кушнір та ін. Серія: Педагогічні науки. Кіровоград: РВВ КДПУ ім. В. Винниченка, 2015. Випуск 139. 316 с.

20. Сисоєва С.О. Основи педагогічної творчості : підруч. Київ : Міленіум, 2006. $346 \mathrm{c}$.

21. Смолина Е.А. Современный урок музыки : творческие приемы и задания. Ярославль : Академия развития, 2007. 128 с.

22. Сухомлинский В.А. Павлышская средняя школа. Обобщение опыта учебно-воспитательной работы сельской средней школы. Москва : Просвещение, 1969. 400 с.

23. Теплов Б.М. Психологические основы художественного воспитания. Москва, Ленинград : Изд-во АПН РСФСР, 1947. 168 с.

24. Філософія: підручник / за заг. ред. М.І. Горлача, В.Г. Кременя, В.К. Рибалки. Київ, Харків : Консум, 2000. 548 с.

25. Философский словарь / под ред. И.Т. Фролова. Москва : Политиздат, 1981. 4-е изд. 445 с.

26. Хуа Вей. Педагогічні умови формування творчого потенціалу майбутніх учителів музики. Наукові записки / ред. кол.: В.Ф. Черкасов, В.В. Радул, Н.С. Савченко та ін. Серія: Педагогічні науки. Кропивницький : РВВ ЦДПУ ім. В. Винниченка, 2017. Випуск 157. 300 с.

27. Шакуров Р.Х. Творческий рост педагога. Москва : Знание, 1985.80 с.

28. Яківчук Г.В. Виховання творчої особистості майбутнього вчителя музики в процесі вивчення українського музичного фольклору : дис. ... канд. пед. наук : 13.00.07. Київ, 2009. 267 с.

\section{References:}

1. Anan'ev B.G. (1968). Chelovek kak predmet poznaniya [Human being as a subject of knowledge]. Leningrad: Leningraskiy universitet. (in Russian)

2. Baranova N. (2003). Psykhologhichnyj klimat u kolektyvi [Psychological climate in the team]. Kyiv: Zaghaljnopedaghoghichni ghazety. (in Ukrainian)

3. Ghramatjuk O. (2015). Diaghnostyka stanu rozvytku tvorchoji aktyvnosti uchniv 9-11 klasiv [Diagnosis of development state of creativity among pupil's activity 9-11 grades]. Naukovi zapysky [Scientific notes], vol. 139, pp. 224-228.

4. Dovzhenok Gh.V. (1981). Ukrajinsjkyj dytjachyj foljklor: virshovani zhanry [Ukrainian children's folklore: poem genres]. Kyiv: Naukova Dumka. (in Ukrainian) 
5. Zaghvjazynsjkyj V.I. (2000). Pedaghoghichna tvorchistj uchytelja [Pedagogical creativity of a teacher]. Pedaghoghichna tvorchistj $i$ majsternistj [Pedagogical creativity and professionalism]. Kyiv: IZMN, p. 168.

6. Ivanenko A. (2014). Metodychni zasady formuvannja khudozhnjo-tvorchoji samorealizaciji ditej 4-5 rokiv u procesi muzychnykh zanjatj [Methodical principles of modelling artistic and self-organisational formation creativity of children 4-5 years in the process of music lessons]. Naukovyj chasopys Nacionaljnogho pedaghoghichnogho universytetu imeni M.P. Draghomanova [Scientific journal of National pedagogical Drahomanov University], vol. 16(21), no. 2, pp. 156-159.

7. Ghoncharenko S. (1997). Ukrajinsjkyj pedaghoghichnyj slovnyk [Ukrainian pedagogical vocabulary]. Kyiv: Lybidj. (in Ukrainian)

8. Engel'meyer P.K. (1910). Teoriya tvorchestva [Theory of creativity]. Moskov: Obrazovanie. (in Russian)

9. Klepykov O.I. (1996). Osnovy tvorchosti osoby [The basics of creative personality]. Kyiv: Vyshha shkola. (in Ukrainian)

10. Kratkiy psikhologicheskiy slovar' [The brief psychological vocabulary] (1985). Moskov: Politizdat. (in Russian)

11. Lystopad O.A. (2013). Diaghnostuvannja tvorchogho potencialu osobystosti dytyny [Diagnosis of creative potential of child personality]. Nauka i osvita [Science and education], vol. 3, pp. 99-101.

12. Luk A.N. (1978). Psikhologiya tvorchestva [Psychology of creativity]. Moskov: Nauka. (in Russian)

13. Lukanovsjka A.V. (2010). Tvorchij potencial osobystosti : strukturni komponenty [Creative potential of a personality]. Problemy suchasnoji psykhologhiji [Problems of a modern psychology], vol. 8, pp. 635-643.

14. Matyushkin A.M. (1972). Problemnye situatsii v myshlenii $i$ obuchenii [Problem situation in thinking and learning]. Moskov: Pedagogika. (in Russian)

15. Molyako V.A. (1978). Psikhologiya tvorcheskoy deyatel'nosti [Psychology of creative activity]. Kyiv: Znanie. (in Ukrainian)

16. Nikitina G.V. (1992). Formirovanie tvorcheskikh umeniy v protsesse professional'nogo obucheniya [Formation of creative skills in the process of professional training]. Sankt-Peterburg. (in Russian)

17. Pavlenko O.M.(2014). Dzhazova improvizacija jak zasib rozvytku tvorchykh vminj majbutnjogho vchytelja muzyky [Jazz improvisation as a means of developing creative skills of a future music teacher]. Naukovyj chasopys Nacionaljnogho pedaghoghichnogho universytetu imeni M.P. Draghomanova [Scientific journal of National pedagogical Drahomanov University], vol. 16(21), no. 2, pp. 71-75.

18. Platonov K.K. (1986). Struktura i razvitie lichnosti [Structure and development of a personality]. Moskov: Nauka. (in Russian).

19. Sachok V. (2015). Osoblyvosti form tvorchoji roboty vchytelja muzychnogho mystectva z uchnjamy pochatkovoji shkoly [Features of creative work form of music art teacher with pupils of elementary school]. Naukovi zapysky [Scientific journal, vol. 139, pp. 197-201.

20. Sysojeva S.O. (2006). Osnovy pedaghoghichnoji tvorchosti [The basics of pedagogical creativity]. Kyiv: Milenium. (in Ukrainian) 
21. Smolina E.A. (2007). Sovremennyy urok muzyki : tvorcheskie priemy $i$ zadaniya [Modern music lesson: creative techniques and tasks]. Yaroslavl: Akademiya razvitiya. (in Russian)

22. Sukhomlinskiy V.A. (1969). Pavlyshskaya srednyaya shkola. Obobshchenie opyta uchebno-vospitatel'noy raboty sel'skoy sredney shkoly [Pavlysh secondary school. Generalization of the experience of educational work process in a rural secondary school]. Moskov: Prosveshchenie. (in Russian)

23. Teplov B.M. (1947). Psikhologicheskie osnovy khudozhestvennogo vospitaniya [Psychological basics of art education]. Moskov, Leningrad: APN RSFSR. (in Russian)

24. Filosofija [Philosophy] (2000). Kyiv, Kharkiv: Konsum. (in Ukrainian)

25. Filosofskiy slovar' [Philosophical dictionary] (1981). Moskov: Politizdat, Philosophical dictionary. (in Russian)

26. Khua Vej. (2017). Pedaghoghichni umovy formuvannja tvorchogho potencialu majbutnikh uchyteliv muzyky [Pedagogical conditions of creative potentional formation of future music teachers]. Naukovi zapysky [Scientific journal], vol. 157, pp. $245-250$.

27. Shakurov R.Kh. (1985). Tvorcheskiy rost pedagoga [Creative growth of pedagogue]. Moskov: Znanie. (in Russian)

28. Jakivchuk Gh.V. (2009). Vykhovannja tvorchoji osobystosti majbutnjogho vchytelja muzyky $v$ procesi vyvchennja ukrajinsjkogho muzychnogho foljkloru [Upbringing of creative personality of future music teacher in the process of learning Ukrainian music folklore] (PhD Thesis), Kyiv. 